\title{
Free-living ixodid ticks in an urban Atlantic Forest fragment, state of Rio de Janeiro, Brazil
}

\author{
Carrapatos ixodídeos de vida livre em um fragmento urbano de Mata Atlântica, \\ Estado do Rio de Janeiro, Brasil \\ Michele da Costa Pinheiro ${ }^{1 *}$; Elizabete Captivo Lourenço²; Priscilla Maria Peixoto Patrício²; \\ Iwine Joyce Barbosa de Sá-Hungaro ${ }^{1}$; Kátia Maria Famadas ${ }^{1,2}$
}

\begin{abstract}
${ }^{1}$ Laboratório de Ixodologia, Departamento de Parasitologia Animal, Universidade Federal Rural do Rio de Janeiro - UFRRJ, Seropédica, RJ, Brasil

${ }^{2}$ Laboratório de Morfofisiologia de Ácaros, Departamento de Parasitologia Animal, Universidade Federal Rural do Rio de Janeiro - UFRRJ, Seropédica, RJ, Brasil
\end{abstract}

Received October 22, 2013

Accepted March 13, 2014

\begin{abstract}
As a consequence of the importance of ticks in forests in protected areas, was conducted survey of species of free-living ticks in the Natural Park Municipal Curió, state of Rio de Janeiro, Brazil. Monthly samples were taken by dragging method, dry ice traps and visual search in two transects. Adults and nymphs of Amblyomma cajennense $(\mathrm{n}=147)$, Amblyomma brasiliense $(\mathrm{n}=4)$ and Amblyomma parvum $(\mathrm{n}=1)$ were collected. This is the first occurrence of $A$. parvum in the state. No correlation was found between the abundance of stages of $A$. cajennense and rainfall, temperature and relative humidity. The highest abundances of adults were in the months of January and May, and nymphs in September and October. The low diversity of parasites on Curió Park can be attributed to the proximity of households with pets, which would also explain the higher abundance of $A$. cajennense that is commonly found in areas impacted by anthropogenic pressure.
\end{abstract}

Keywords: Amblyomma brasiliense, Amblyomma cajennense, Amblyomma parvum.

\section{Resumo}

Como consequência da importância dos carrapatos em áreas florestais como Unidades de Conservação, foi realizado levantamento das espécies de carrapatos de vida livre no Parque Natural Municipal Curió, Estado do Rio de Janeiro, Brasil. Foram realizadas coletas mensais através de arrasto, armadilhas de gelo seco e busca visual, em dois transectos. Foram coletados adultos e ninfas de Amblyomma cajennense $(\mathrm{n}=147)$, Amblyomma brasiliense $(\mathrm{n}=4)$ e Amblyomma parvum $(\mathrm{n}=1)$. Esta é a primeira ocorrência de $A$. parvum no Estado. Não foi encontrada correlação entre a abundância de estágios de $A$. cajennense e precipitação, temperatura e umidade relativa do ar. As maiores abundâncias de adultos foram nos meses de janeiro e maio; e ninfas em setembro e outubro. A baixa diversidade de carrapatos no Curió pode ser atribuída à proximidade de residências com animais domésticos, o que também explicaria a maior abundância de $A$ cajennense, que é comumente encontrada em áreas impactadas por pressão antrópica.

Palavras-chave: Amblyomma brasiliense, Amblyomma cajennense, Amblyomma parvum.

Despite the high socio-environmental interest of more preserved areas such as Full Protection Conservation Units, reports about outbreaks of diseases transmitted by ticks on wild animal and the growing practice of ecotourism, few surveys have focused on free-living ticks. The importance of such studies is indisputable, considering the fact that public parks, which are visited by large

*Corresponding author: Michele da Costa Pinheiro

Laboratório de Ixodologia, Departamento de Parasitologia Animal,

Universidade Federal Rural do Rio de Janeiro - UFRRJ,

BR-465, Km 07, CEP 23890-000, Seropédica, RJ, Brasil

e-mail: michelezootec@gmail.com numbers of people, often contain small wild animals and their ticks. The combination of ticks of wild animals, circulating pathogens and humans favors the emergence of zoonosis and hence of public health problems (CISAK et al., 2005; TOLEDO et al., 2008; QUEIROGAS, 2010).

Based on these arguments, the purpose of this study was to conduct a survey of free-living tick species in Curió Municipal Nature Park, examining their life stages and sex ratio throughout the sampling period. Because forest areas may differ from open habitats such as grasslands, in terms not only of vegetation type but also weather patterns (ARZUA, 2007; TACK et al., 2012), 
an analysis was also made of the abundances of species found as a function of micro- and mesoclimatic conditions.

Curió Municipal Nature Park (Curió Park) (22³3' - 22³6’ S and $\left.43^{\circ} 40^{\prime}-43^{\circ} 43^{\prime} \mathrm{W}\right)$ is a Full Protection Conservation Unit, located in the municipality of Paracambi, Rio de Janeiro state, Brazil. The park encompassing forest remnants with areas in stages of early, intermediate and late regeneration, and many watersheds providing water for human population.

The region's climate falls within the Aw macroclimate, according to the Köppen-Geiger climate classification (PEEL et al., 2007), being characterized by minimum temperature of approximately $18^{\circ} \mathrm{C}$ in the coldest month and minimum precipitation of less than $60 \mathrm{~mm}$ in the driest month of the year (KOTTEK et al., 2006). Mesoclimatic data on rainfall, temperature and relative humidity from January to October 2012 were provided by the Meteorological Station of the Environmental Monitoring Laboratory, Paracambi Institute of Technology (Figure 1). Microclimatic data on temperature and relative humidity were also obtained by means of a digital hygrometer placed at ground level, on the collection day and site, except in February. Samples were not collected on rainy days.

The collections were authorized by Biodiversity Authorization and Information System from Chico Mendes Institute for

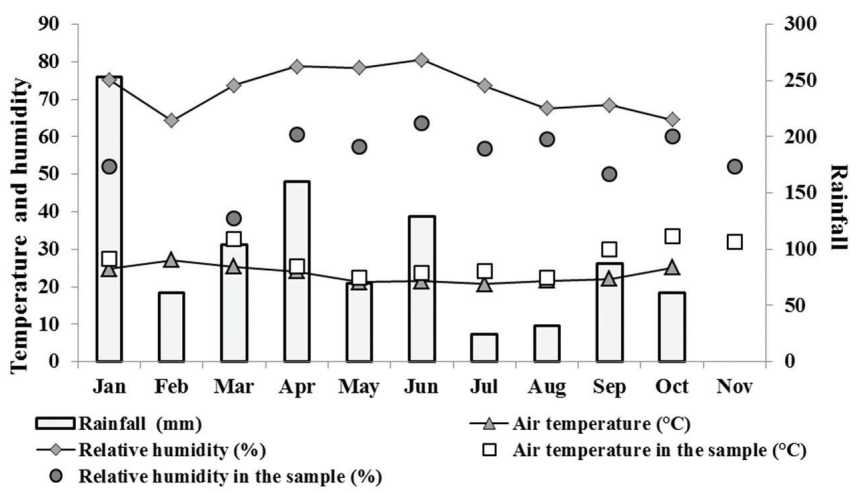

Figure 1. Variations in temperature, relative humidity and precipitation based on monthly averages for the period of Jan to Oct 2012, provided by the Meteorological Station of the Environmental Monitoring Laboratory of the Paracambi Institute of Technology. Average temperature and relative air humidity on the tick sampling day in Curió Municipal Nature Park, Paracambi, RJ, Brazil.
Biodiversity Conservation, (SISBIO/ICMBio), Brazilian Environmental Ministry, under Permit \# 32687-1, and by the Paracambi Municipality Department of Environment and Sustainable Development.

Tick specimens were collected on two line transects along two trails: Jequitibá Rosa (800 m) (22³5'53” S, 4342’23” W) and

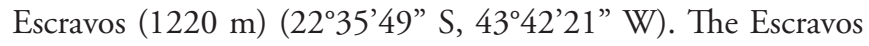
trail is under less anthropogenic pressure than the Jequitibá Rosa trail, since the latter is more frequented due to its proximity to houses. The presence of domestic animals such as dogs (Canis lupus familiaris Linnaeus, 1758), chickens (Gallus gallus domesticus (Linnaeus, 1758)) and cattle (Bos taurus Linnaeus, 1758) was observed on the Jequitibá Rosa trail. The maximum distance between the two trails is approximately $930 \mathrm{~m}$ and the minimum distance is $67 \mathrm{~m}$.

Specimens were monthly collected from January to November 2012. Six traps contained approximately $500 \mathrm{~g}$ of dry ice cubes (OLIVEIRA et al., 2000) were set up about 20 meters apart along each trail and left there from 10 a.m. to 2 p.m.

Tick dragging was performed by hand according Beldomenico et al. (2003). The cloth was dragged along the ground for a distance of about 150 meters on each trail where the dry ice baited traps were deployed. The researchers performed a visual search of the vegetation and ground as they walked along the trails, and on their bodies and clothing at the end of the trails.

The adult ticks were identified using the dichotomous keys of Onofrio et al. (2006), while the nymph stage was identified using that of Martins et al. (2010).

The chi-square test was used to monthly analyze the proportion of tick life stages and sex, as well as the total abundance on each trail. To correlate the abundance of nymph and adult ticks with average temperature, relative humidity (micro- and mesoclimate) and monthly rainfall (mesoclimate), a simple linear regression test was performed using PAST version 1:44 software (HAMMER et al. 2001). Due to technical problems in obtaining data micro- and mesoclimate data in February and November, respectively, those months were not included in this analysis. Our analyses involved only the most abundant species and did not include data collected by the visual search method, because we believe that the bias of this methodology could influence our findings.

A total of 152 ticks were collected, comprising adults $(n=46)$ and nymphs $(\mathrm{n}=106)$ of three species of Amblyomma: Amblyomma cajennense Fabricius, 1787 (96.7\%), Amblyomma brasiliense Aragão,

Table 1. Ticks found in Curió Municipal Nature Park in Paracambi, RJ, Brazil.

\begin{tabular}{|c|c|c|c|c|c|c|c|c|c|c|c|c|c|c|}
\hline \multirow{2}{*}{$\begin{array}{c}\text { Trails } \\
\text { Escravos }\end{array}$} & \multirow[t]{2}{*}{ Method } & \multicolumn{4}{|c|}{ A. cajennense } & \multicolumn{4}{|c|}{ A. brasiliense } & \multicolumn{4}{|c|}{ A. parvum } & \multirow[t]{2}{*}{ Tota } \\
\hline & & $\mathbf{L}$ & $\mathbf{N}$ & $\mathbf{M}$ & $\mathbf{F}$ & $\mathbf{L}$ & $\mathbf{N}$ & $\mathbf{M}$ & $\mathbf{F}$ & $\mathbf{L}$ & $\mathbf{N}$ & $\mathbf{M}$ & $\mathbf{F}$ & \\
\hline & Dry ice & - & 18 & 1 & 6 & - & 1 & - & - & - & - & - & - & 26 \\
\hline & Dragging & - & - & 1 & - & - & - & - & - & - & - & - & - & 1 \\
\hline & Visual search & - & 6 & 2 & - & - & - & - & - & - & - & 1 & - & 9 \\
\hline \multicolumn{15}{|c|}{ Jequitibá-Rosa } \\
\hline & Dry ice & - & 74 & 12 & 22 & - & 3 & - & - & - & - & - & - & 111 \\
\hline & Dragging & - & 2 & - & - & - & - & - & - & - & - & - & - & 2 \\
\hline & Visual search & - & 2 & 1 & - & - & - & - & - & - & - & - & - & 3 \\
\hline Total & & - & 102 & 17 & 28 & - & 4 & - & - & - & - & 1 & - & 152 \\
\hline
\end{tabular}

L: Larvae; N: Nymphs; M: Male; F: Female. 
1908 (2.6\%) and Amblyomma parvum Aragão, 1908 (0.7\%) (See Table 1). Larva stage specimens were not obtained in the collections.

A larger number of the most abundant species, $A$. cajennense, was captured on the Jequitibá Rosa trail than on the Escravos trail ( $p<0.05, \chi^{2}>3.84$ ) (Table 1). Nymphs were more abundant in September $(n=46)$ and October $(n=28)$, surpassing the abundance of adults in the months of August to November. The highest abundances of adults were found in January $(n=9)$ and May $(n=8)$ (Figure 2a). The number of females was higher than males in most months, presenting a statistical significance in September $\left(\mathrm{p}<0.05, \chi^{2}>3.84\right)$ (Figure $\left.2 b\right)$.

Throughout the year, the minimum recorded temperature at the collection points (microclimate) was $21^{\circ} \mathrm{C}$ in April and the maximum was $34^{\circ} \mathrm{C}$ in October, while the minimum and maximum relative humidity were recorded in August (34\%) and June (70\%). Values of temperature, relative humidity (micro- and mesoclimate) and rainfall (mesoclimate) are listed in Figure 1. No correlation was found between $A$. cajennense adult and nymph abundance and temperature, relative humidity and rainfall.

Despite our expectation of a greater diversity of ticks in an area with denser vegetation cover and diversity of host species, especially on the less disturbed trail, Escravos, the forest environment of the trails in the park did not display as marked a differentiation in free-living ticks as that reported previously for anthropized areas such as pastures (SOUZA; SERRA-FREIRE, 1992, 1994; GUEDES; LEITE, 2008).

The low diversity of ticks found in this park may be attributed to the fact that the sampling points were located at its outer boundaries, and hence close to some residences with domestic animals. This would also explain the tendency for a greater abundance of $A$. cajennense in the more disturbed area (Jequitibá Rosa trail). This species is commonly found in high abundance
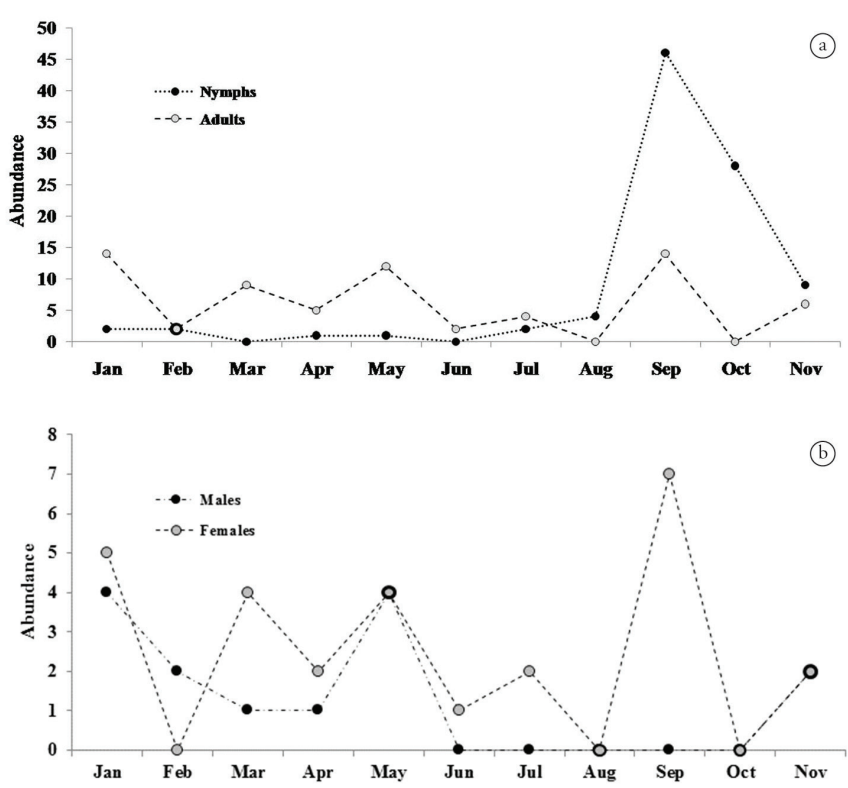

Figure 2. Monthly distribution of Amblyomma cajennense in Curió Municipal Nature Park in Paracambi, RJ, Brazil. a) adult males and females, b) nymphs and adults. in impacted areas under high anthropogenic pressure (ARZUA, 2007; CANÇADO et al., 2008; SILVEIRA; FONSECA, 2011). Previous studies have reported that the prevalence of $A$. cajennense in tropical forests is low, although it is well adapted to a variety of environments (ESTRADA-PEŃA et al., 2004; SZABÓ et al., 2007; VERONEZ et al., 2010).

With regard to the abundance of stages during the year, the findings of this study are consistent with those of Veronez et al. (2010), who observed a similarity in the seasonal activity of A. cajennense in rural areas and natural environments in southeastern Brazil. Moreover, some studies have reported peak abundances of larvae between March and June, of nymphs between July and November, and of adults between November and March (OLIVEIRA et al., 2000; SZABÓ et al., 2007; TOLEDO et al., 2008). Another study conducted in the municipality of Paracambi in an area of pastureland (SOUZA; SERRA-FREIRE, 1994) also found a higher abundance of nymphs between July and November.

The distribution of $A$. brasiliense is known to be limited to Brazil, Argentina and Paraguay (GUGLIELMONE et al., 2003; ONOFRIO et al., 2006). Most of the records of A. brasiliense in Brazil are derived from studies conducted in forest areas (OGRZEWALSKA et al., 2009; SZABÓ et al., 2009; SABATINI et al., 2010; SILVEIRA; FONSECA, 2011) like this work, which may demonstrate the association of this species with preserved environments under lower anthropic pressure. The main hosts of $A$. brasiliense are wild animals such as the spotted paca (Cuniculus paca Linnaeus, 1766), agouti (Dasyprocta sp.) and white-lipped peccary (Tayassu pecari Link, 1795) (ARAGÃO, 1936; GUIMARÁES et al., 2001), having records occurrence in the park (ITPA, 2010).

Amblyomma parvum is widely distributed and has been reported from southern Mexico to Argentina (NAVA et al. 2008) and in Brazil it has already been found in several states and in state of Rio de Janeiro is the first record. Amblyomma parvum has an extensive list of hosts comprising 47 species, not having until this moment been linked to a primary host (NAVA et al., 2008). The fact that the specimen in question was captured in the wild environment did not allow us to clarify which host it would be associated to in Curió Park. Some of the listed hosts for A. parvum are present in the Park (ITPA, 2010).

The factors involved in the distribution of $A$. parvum in Neotropic region are still not known and need further clarification, their occurrence in various biomes and environments as well as wide range of host species suggest that this species has high environmental plasticity, despite its low abundance.

With regard to the absence of larvae in this study, Oliveira et al. (2000) reported that larvae have little locomotor capacity and that their activity is inhibited by high concentrations of $\mathrm{CO}_{2}$. As for the tick dragging method, although it is frequently used for capturing free-living larvae (PETRY et al., 2010; DANTASTORRES et al., 2013), it was not efficient in this area, probably because the undergrowth, bushes and trees along the edges of the trails hindered it. Tack et al. (2011) had already shown that this method might not be very suitable for trail areas and would probably result in higher captures of adults and nymphs than of larvae. Labruna et al. (2005), Szabó et al. (2009) and Terassini et al. 
(2010) suggested that visual searches in forest areas are more efficient for sampling ticks, but that was not the case in the present study.

Tick sampling should be performed in Conservation Units, since they still preserve a structure of fauna and flora more closely resembling the natural environment of these arthropods, providing more information about their biology. In southeastern Brazil, these areas correspond to Atlantic Forest remnants, which are favorable environments for ticks due to their abiotic and biotic characteristics, such as high percentages of relative humidity and moderate temperatures, allied to the presence of natural hosts (TACK et al., 2012). Some studies have shown a correlation between tick abundance and the environment (ARZUA, 2007; JAENSON et al., 2009; TACK et al., 2012). However, whatever differences are found appear to be more related to the presence of hosts than to the actual structure of the landscape (ESTRADAPEÑA, 2003; ALLAN et al., 2003; BROWNSTEIN et al., 2005; TACK et al., 2012).

In the case of parks that are open public visitation and may receive a large number of people, survey studies of ticks and analysis of pathogenic agents are needed due to possible contact with humans that can cause consequences for public health, with the transmission zoonosis (TOLEDO et al., 2008; QUEIROGAS, 2010) have been reported in municipalities close to Paracambi (ROZENTAL et al., 2002; LAMAS et al., 2008; SPOLIDORIO et al., 2012), and that wild animals roam freely in forested areas, should all serve as a warning that this area poses a potential risk for this zoonosis.

However, only studies to identify the presence of pathogens in the samples collected here (unpublished data) and surveys conducted in other areas of Curió Park will be helpful in estimating the real risk to the park's future visitors.

\section{Acknowledgments}

The authors thank the staff of the CEDAE - Paracambi station, for their hospitality, the research funding agencies FAPERJ, CAPES and CNPq (Brazil) for their financial support, and the PPGCV/ UFFRJ for its logistical support, especially laboratory technician Mr. Ivan Serafim.

\section{References}

Allan BF, Keesing F, Ostfeld RS. Effect of forest fragmentation on Lyme disease risk. Conserv Biol 2003; 17(1): 267-272. http://dx.doi. org/10.1046/j.1523-1739.2003.01260.x

Aragão HB. Ixodidas brasileiros e de alguns paizes limitrophes. Mem Inst Oswaldo Cruz 1936; 31(4): 759-841. http://dx.doi.org/10.1590/ S0074-02761936000400004

Arzua M. Diversidade de carrapatos (Acari: Ixodidae) de remanescentes de floresta estacional semidecidual e de floresta ombrófila densa, no estado do Paraná. [Tese]. Paraná: Universidade Federal do Paraná; 2007. PMid:17464485.

Beldomenico PM, Baldi CJ, Antoniazzi LR, Orduna GM, Mastropaolo M, Macedo AC, et al. Ixodid ticks (Acari: Ixodidae) present at Parque Nacional El Rey, Argentina. Neotrop Entomol 2003; 32(2): 273-277. http://dx.doi.org/10.1590/S1519-566X2003000200012
Brownstein JS, Skelly DK, Holford TR, Fish D. Forest fragmentation predicts local scale heterogeneity of Lyme disease risk. Oecologia 2005; 146(3): 469-475. PMid:16187106. http://dx.doi. org/10.1007/s00442-005-0251-9

Cançado PHD, Piranda EM, Mourão GM, Faccini JLH. Spatial distribution and impact of cattle-raising on ticks in the Pantanal region of Brazil by using the $\mathrm{CO}_{2}$ tick trap. Parasitol Res 2008; 103(2): 371377. PMid:18454288. http://dx.doi.org/10.1007/s00436-008-0982-8

Cisak E, Chmielewska-Badora J, Zwolinski J, Wojcik-Fatla A, Polak J, Dutkiewicz J. Risk of tick-borne bacterial diseases among workers of Roztocze National Park (south-eastern Poland). Ann Agric Environ Med 2005; 12(1): 127-132. PMid:16028877.

Dantas-Torres F, Lia RP, Capelli G, Otranto D. Efficiency of flagging and dragging for tick collection. Exp Appl Acarol 2013; 61(1): 119-127. PMid:23417703. http://dx.doi.org/10.1007/s10493-013-9671-0

Estrada-Peña A. The relationships between habitat topology, critical scales of connectivity and tick abundance Ixodes ricinus in a heterogeneous landscape in northern Spain. Ecography 2003; 26(5): 661-671. http:// dx.doi.org/10.1034/j.1600-0587.2003.03530.x

Estrada-Peña A, Guglielmone AA, Mangold AJ. The distribution an ecological 'preferences' of the tick Amblyomma cajennense (Acari: Ixodidae), an ectoparasite of humans and other mammals in the Americas. Ann Trop Med Parasitol 2004; 98(3): 283-292. PMid:15119974. http:// dx.doi.org/10.1179/000349804225003316

Guedes E, Leite RC. Dinâmica sazonal de estádios de vida livre de Amblyomma cajennense e Amblyomma dubitatum (Acari: Ixodidae) numa área endêmica para febre maculosa, na região de Coronel Pacheco, Minas Gerais. Rev Bras Parasitol Vet 2008; 17(S1): 78-82. PMid:20059821.

Guglielmone AA, Estrada-Peńa A, Keirans JE, Robbins RG. Ticks (Acari: Ixodidae) of the Neotropical Zoogeographic Region. Special Publication. Atalanta: International Consortium on Ticks and TickBorne Diseases; 2003.

Guimarães JH, Tucci EC, Barros-Battesti DM. Ectoparasitos de Importância Veterinária. Plêiade; 2001.

Hammer O, Harper DAT, Rian PD. Past: Palaeonthological statistics software package for education and data analysis. version. 1.37. 2001 [cited 2012 Jul 20]. Available from: http://palaeo-electronica. org/2001_1/past/issue1_01.htm.

Instituto Terra de Preservação Ambiental - ITPA. Secretaria Municipal do Meio Ambiente de Paracambi - SEMA. Plano de Manejo do Parque Natural Municipal do Curió. ITPA; 2010.

Jaenson TGT, Eisen L, Comstedt P, Mejlon, HA, Lindgren E, Bergström $S$ et al. Risk indicators for the tick Ixodes ricinus and Borrelia burgdorferi sensu lato in Sweden. Med Vet Entomol 2009; 23(3): 226-237. PMid:19712153. http://dx.doi.org/10.1111/j.1365-2915.2009.00813.x

Kottek M, Grieser J, Beck C, Rudolf B, Rubel F. World map of the KöppenGeiger climate classification updated. Meteorol Z 2006; 15(3): 259-263. http://dx.doi.org/10.1127/0941-2948/2006/0130

Labruna MB, Camargo LMA, Terrassini FA, Ferreira F, Schumaker TTS, Camargo EP. Ticks (Acari: Ixodidae) from the state of Rondônia, western Amazon, Brazil. Syst Appl Acarol 2005; 10(1): 17-32.

Lamas C, Curi A, Bóia MN, Lemos ERS. Human bartonellosis: seroepidemiological and clinical features with an emphasis on data from Brazil - A Review. Mem Inst Oswaldo Cruz 2008; 103(3): 221235. PMid:18592096. http://dx.doi.org/10.1590/S007402762008000300001 
Martins TF, Onofrio CV, Barros-Battesti DM, Labruna MB. Nymphs of the genus Amblyomma (Acari: Ixodidae) of Brazil: descriptions, redescriptions, and identification key. Ticks Tick Borne Dis 2010; 1(2): 75 99. PMid:21771514. http://dx.doi.org/10.1016/j.ttbdis.2010.03.002

Nava S, Szabó MPJ, Mangold AJ, Guglielmone AA. Distribution, hosts, 16S rDNA sequences and phylogenetic position of the Neotropical tick Amblyomma parvum (Acari: Ixodidae). Ann Trop Med Parasitol 2008; 102(5): 409-425. PMid:18577332. http://dx.doi. org/10.1179/136485908X278883

Ogrzewalska M, Pacheco RC, Uezu A, Richtzenhain LJ, Ferreira F, Labruna MB. Ticks (Acari: Ixodidae) infesting birds in an Atlantic rain forest region of Brazil. J Med Entomol 2009; 46(5): 1225-1229. PMid:19769058. http://dx.doi.org/10.1603/033.046.0534

Oliveira PR, Borges LMF, Lopes CML, Leite RC. Population dynamics of the free-living stages of Amblyomma cajennense (Fabricius, 1787) (Acari: Ixodidae) on pastures of Pedro Leopoldo, Minas Gerais State, Brazil. Vet Parasitol 2000; 92(4) 295-301. http://dx.doi.org/10.1016/ S0304-4017(00)00322-8

Onofrio VC, Venzal JM, Pinter A, Szabó MPJ. Família Ixodidae: características gerais, comentários e chave para gêneros. In: BarrosBattesti DM, Arzua M, Bechara GH. Carrapatos de importância Médico-Veterinária da Regiāo Neotropical. São Paulo: ICTTD- Instituto Butantan; 2006. p. 29-39.

Peel MC, Finlayson BL, McMahon TA. Updated world map of the Köppen-Geiger climate classification. Hydrol Earth Syst Sci 2007; 11: 1633-1644. http://dx.doi.org/10.5194/hess-11-1633-2007

Petry WK, Foré SA, Fielden LJ, Kim HJ. A quantitative comparison of two sample methods for collecting Amblyomma americanum and Dermacentor variabilis (Acari: Ixodidae) in Missouri. Exp Appl Acarol 2010; 52(4): 427-438. PMid:20585839. http://dx.doi. org/10.1007/s10493-010-9373-9

Queirogas VL. Capivaras (Rodontia) e Carrapatos (Acari: Ixodidae): Alteraçōes ecológicas e a interação do hospedeiro e parasita em áreas urbanas [Dissertação]. Uberlândia: Universidade Federal de Uberlândia; 2010.

Rozental T, Bustamante MC, Amorim M, Serra-Freire NM, De Lemos ERS. Evidence of spotted fever group Rickettsiae in state of Rio de Janeiro, Brazil. Rev Inst Med Trop S Paulo 2002; 44(3): 155-158. PMid:12163909. http://dx.doi.org/10.1590/S0036-46652002000300008

Sabatini GS, Pinter A, Nieri-Bastos FA, Marcili A, Labruna MB. Survey of ticks (Acari: Ixodidae) and their Rickettsia in an Atlantic rain forest reserve in the state of São Paulo, Brazil. J Med Entomol 2010; 47(5): 913916. PMid:20939390. http://dx.doi.org/10.1603/ME10073
Silveira AK, Fonseca AH. Caracterização de ambientes com potencial para ocorrência de carrapatos transmissores de agentes patogênicos para humanos. Boletim do Parna Itatiaia 2011; 13. PMid:21855061.

Souza AP, Serra-Freire NM. Variação sazonal dos estádios adultos de Amblyomma cajennense e Anocentor nitens, como parasitas de cavalos, no município de Itaguaí, RJ, Brasil. Rev Bras Parasitol Vet 1992; 1(1): 31-34.

Souza AP, Serra-Freire NM. Variação sazonal da fase não parasitária de Amblyomma cajennense e Anocentor nitens, no município de Itaguaí, RJ: avaliação epidemiológica e metodológica. Rev Univ Rural, Sér Ciênc da Vida 1994; 16(1-2): 67-74.

Spolidorio MG, Andreoli GS, Martins TF, Brandão PE, Labruna, MB. Rickettsial infection in ticks collected from road-killed wild animals in Rio de Janeiro, Brazil. J Med Entomol 2012; 49(6): 1510-1514. PMid:23270184. http://dx.doi.org/10.1603/ME12089

Szabó MPJ, Castro MB, Ramos HGC, Garcia MV, Castagnolli KC, Pinter A, et al. Species diversity and seasonality of free-living ticks (Acari: Ixodidae) in the natural habitat of wild Marsh deer (Blastocerus dichotomus) in Southeastern Brazil. Vet Parasitol 2007; 143(2): 147-154. PMid:16962241. http://dx.doi.org/10.1016/j.vetpar.2006.08.009

Szabó MPJ, Labruna MB, Garcia MV, Pinter A, Castagnolli KC, Pacheco RC, et al. Ecological aspects of the free-living ticks (Acari: Ixodidae) on animal trails within Atlantic rainforest in south-eastern Brazil. Ann Trop Med Parasitol 2009; 103(1): 57-72. PMid:19173777. http://dx.doi. org/10.1179/136485909X384956

Tack W, Madder M, Baeten L, Vanhellemont M, Gruwez R, Verheyen $\mathrm{K}$. Local habitat and landscape affect Ixodes ricinus tick abundances in forests on poor, sandy soils. Forest Ecol Manag 2012; 265: 30-36. http:// dx.doi.org/10.1016/j.foreco.2011.10.028

Tack W, Madder M, Frenne P, Vanhellemont M, Gruwez R, Verheyen $\mathrm{K}$. The effects of sampling method and vegetation type on the estimated abundance of Ixodes ricinus ticks in forests. Exp Appl Acarol 2011; 54(3): 285-292. PMid:21431925. http://dx.doi. org/10.1007/s10493-011-9444-6

Terassini FA, Barbieri FS, Albuquerque S, Szabó MPJ, Camargo LMA, Labruna MB. Comparison of two methods for collecting flee-living ticks in the Amazonian Forest. Ticks Tick Borne Dis 2010; 1(4): 194196. PMid:21771528. http://dx.doi.org/10.1016/j.ttbdis.2010.08.002

Toledo RS, Tamekuni K, Haydu VB, Vidotto V. Dinâmica sazonal de carrapatos do gênero Amblyomma (Acari: Ixodidae) em um parque urbano da cidade de Londrina, PR. Rev Bras Parasitol Vet 2008; 17(S1): 50-54.

Veronez VA, Castro MB, Bechara GH, Szabó MPJ. Histopathology of Rhipicephalus sanguineus (Acari: Ixodidae) ticks fed on resistant hosts. Exp Appl Acarol 2010; 50(2): 151-161. PMid:19554460. http://dx.doi. org/10.1007/s10493-009-9286-7 